\title{
Flow intermittency, physico-chemistry and function of headwater streams in an Alpine glacial catchment
}

\author{
C. T. Robinson ${ }^{1,2} \cdot$ D. Tonolla ${ }^{1,2,3} \cdot$ B. Imhof ${ }^{1,2} \cdot$ R. Vukelic ${ }^{1,2} \cdot$ U. Uehlinger ${ }^{1,2}$
}

Received: 4 March 2015 / Accepted: 9 September 2015/Published online: 16 September 2015

(C) Springer Basel 2015

\begin{abstract}
Relatively little is known regarding the extent of intermittent streams or the general ecology of headwaters in alpine catchments with glacial influence. This study quantified the contribution of intermittent streams to the total length of the stream network along with an ecological assessment during spring-summer of headwater streams (higher than 1,900 m above sea level) in the Val Roseg, a high Alpine glacial catchment. Stream network mapping revealed that $c a .90 \%(76.8 \mathrm{~km})$ of the drainage network consisted of intermittent streams. Glacier-fed headwaters experienced diel surface flows in late spring and summer, most going dry during the night due to reduced glacial inputs. In contrast, groundwater-fed streams often went dry in summer with the contraction of groundwater and other subsurface inputs. A principal components analysis of physico-chemical characteristics revealed headwaters to be primarily glacial-fed (kryal), groundwater-fed (krenal), or having a mixed water source. Although quite variable, periphyton biomass reached high levels (ca. $40 \mathrm{mg} \mathrm{m}^{-2} \mathrm{chl}-$ $a, 10 \mathrm{~g} \mathrm{~m}^{-2}$ AFDM) by late spring in most headwaters. Organic matter in transport (seston) ranged from 0.03 to $0.09 \mathrm{mg} \mathrm{L}^{-1}$ mostly consisting of fine particulate organic matter (FPOM: 33-76\%). Hyporheic sediment respiration rates varied considerably, ranging from 0.005 to $0.126 \mathrm{mg} \mathrm{O}_{2} \mathrm{~h}^{-1} \mathrm{~kg}^{-1}$ sediment and primarily related to the amount of loosely attached organic matter. These results
\end{abstract}

C. T. Robinson

Christopher.Robinson@eawag.ch; robinson@eawag.ch

1 Department of Aquatic Ecology, Eawag, 8600 Duebendorf, Switzerland

2 Institute of Integrative Biology, ETH Zürich, Zurich, Switzerland

3 Present Address: ZHAW, Wädenswil, Switzerland indicate that intermittent streams are predominant in alpine landscapes, comprising mostly 1 st to 2 nd order systems, and that ecosystem properties vary substantially among headwater streams likely in relation to annual/daily changes in flow and water source. Such headwaters may contribute strongly to the production, processing and transport of organic matter to downstream waters, especially in light of the expected increase in intermittent streams in alpine catchments experiencing rapid glacial recession.

Keywords Function - Glacier · Hydrology - Intermittent stream $\cdot$ Sediment respiration $\cdot$ Organic matter

\section{Introduction}

Intermittent streams are running waters with a recurrent dry phase that varies in length (Comin and Williams 1994; Larned et al. 2010; Arthington et al. 2014), typically flowing only during wet periods, usually $c a .10-90 \%$ of the year, and mostly following heavy rainfall or snowmelt (Tooth 2000; Datry et al. 2014). Thus intermittent streams experience both zero flow and floods; both being major natural disturbances to aquatic flora and fauna. Intermittent streams usually fall dry once surface runoff ceases, although surface waters can be present as disconnected pools. Surface drying results from different factors such as climatic conditions causing drought, high evapotranspiration, water abstraction, and large vertical water exchange (e.g., downwelling into alluvial or karstic aquifers). Stream drying reduces the flow and connectivity of aquatic habitats (Gasith and Resh 1999; Lake 2003) as well as the extent of subsurface-surface water exchange (Stanley and Boulton 1995), and imposes important ecological constraints (Larned et al. 2007; Vidal-Abarca et al. 2013). 
Flow intermittency is a common feature of streams in arid landscapes where extended dry periods result from low precipitation and high evapotranspiration; indeed, most research on intermittent streams has been done in arid or semi-arid environments like deserts and drylands (Fisher et al. 1982; Stanley et al. 1997; Rocha et al. 2012) or Mediterranean catchments (Gasith and Resh 1999; Acuna et al. 2004; Acuna and Tockner 2010). However, intermittent streams also occur in mesic and temperate environments, for example in headwater streams draining grasslands (Matthews 1988; Covich et al. 1997), summer dry streams of the temperate zone in Oregon, USA (Dieterich and Anderson 1998), forest streams in Australia (Boulton and Lake 1990), karstic streams in Northern Germany (Meyer et al. 2003), and alpine streams (Robinson and Matthaei 2007). Importantly, intermittent streams are expected to become more common in the future but a paucity of knowledge currently exists on the ecology of these systems (Larned et al. 2010; Datry et al. 2014), intermittent alpine streams in particular. The loss in surface flow with intermittency likely inhibits biofilm development and influences organic matter dynamics in streams (Larned et al. 2007; Datry et al. 2014).

Streams of high altitude (alpine) and latitude (arctic) typically experience a dry period between autumn and spring (House et al. 1995; Malard et al. 1999) during which streams may fall dry (cessation of meltwater supply) or completely freeze. In these ecosystems, precipitation falling as snow during winter is stored until spring and mainly released during summer (Röthlisberger and Lang 1987). Intermittency is expected to be a typical feature of alpine headwater streams, particularly those in high gradient areas in alpine landscapes where shallow aquifers limit transient water storage (Robinson and Matthaei 2007) and constrain surface flow after snow-melt cessation (Malard et al. 2000). Apart from intermittency, the hydrology and physicochemistry of alpine headwater streams is dominated by a seasonally changing contribution of different water sources (glacial, groundwater, precipitation) during the annual cycle, in glacial catchments in particular (Malard et al. 1999; Brown et al. 2003; Tockner and Malard 2003, Slemmons et al. 2013). Importantly, headwater streams can contribute significantly to catchment hydrology (Alexander et al. 2007) and overall biodiversity of river networks (Meyer et al. 2007).

There exists relatively few studies on the ecology of alpine headwater streams (e.g., Donath and Robinson 2001; Ruegg and Robinson 2004; but see Lencioni et al. 2012 on the ecology of mountain springs), and the spatial extent of intermittent streams in alpine landscapes is largely unknown (Robinson and Matthaei 2007). Studies in the upper Val Roseg, Switzerland, showed that $75 \%$ of the braided channel network in the glacial floodplain was intermittent (Tockner et al. 1997; Zah et al. 2001, 2003; Malard et al. 2005). However, these particular studies focused only on the main floodplain channels and essentially ignored headwater streams entering the floodplain. Although poorly studied, headwater streams can comprise a high proportion of the channel network in alpine catchments (Reid and Ziemer 1994; Robinson and Matthaei 2007). A primary objective of this study was to examine the spatial extent of intermittent streams in an alpine glacial catchment. In addition, we characterized physicochemistry and ecosystem properties, including functional measures, among different headwater streams from early melt season (early May 2005) until late summer (end August 2005), the period of active surface water dynamics in most Alpine catchments. We expected intermittent streams to predominate in the catchment and that headwaters would vary in ecosystem properties in relation to their dominant water source. Ecosystem properties are discussed in the context of the different stream types based on the results.

\section{Study system}

The Val Roseg $\left(46^{\circ} 29^{\prime} 28^{\prime \prime} \mathrm{N}, 9^{\circ} 53^{\prime} 57^{\prime \prime} \mathrm{E}\right)$ is located in the Bernina massif in the eastern part of the Swiss Alps. The study catchment included the uppermost part of the Roseg valley with an area of $49.5 \mathrm{~km}^{2}$ and elevations ranging from 1,900 to $4,049 \mathrm{~m}$ a.s.l. (Fig. 1). The catchment is drained by the second order Roseg River primarily fed by meltwater from two valley glaciers. A $2.7 \mathrm{~km}$ long and $0.15-0.51 \mathrm{~km}$ wide floodplain is a major geomorphic feature of the Roseg River corridor (inset Fig. 1). A detailed description of the catchment has been given elsewhere (Ward and Uehlinger 2003). The stream network of the study catchment consisted of the floodplain network and the tributary network on both valley sides and was used in the network mapping and analysis described below.

\section{Methods}

\section{Stream network mapping}

A map of the stream network was based on topographic maps (scale, 1:25,000, Federal Office of Topography swisstopo), geo-referenced high resolution aerial photographs (swisstopo) and field mapping using a Global positioning system (GPS) receiver $\left(\mathrm{eTrex}^{\circledR}\right.$ Vista personal navigator $^{\mathrm{TM}}$, Garmin ${ }^{\circledR}$ International Inc., Olathe, KS, USA). GPS accuracy (producer information) was $<15 \mathrm{~m}$ (95\% typical) and between 4 and $15 \mathrm{~m}$ during the mapping period (spring/summer 2005). Detailed stream routes and connections were obtained by walking along channels 

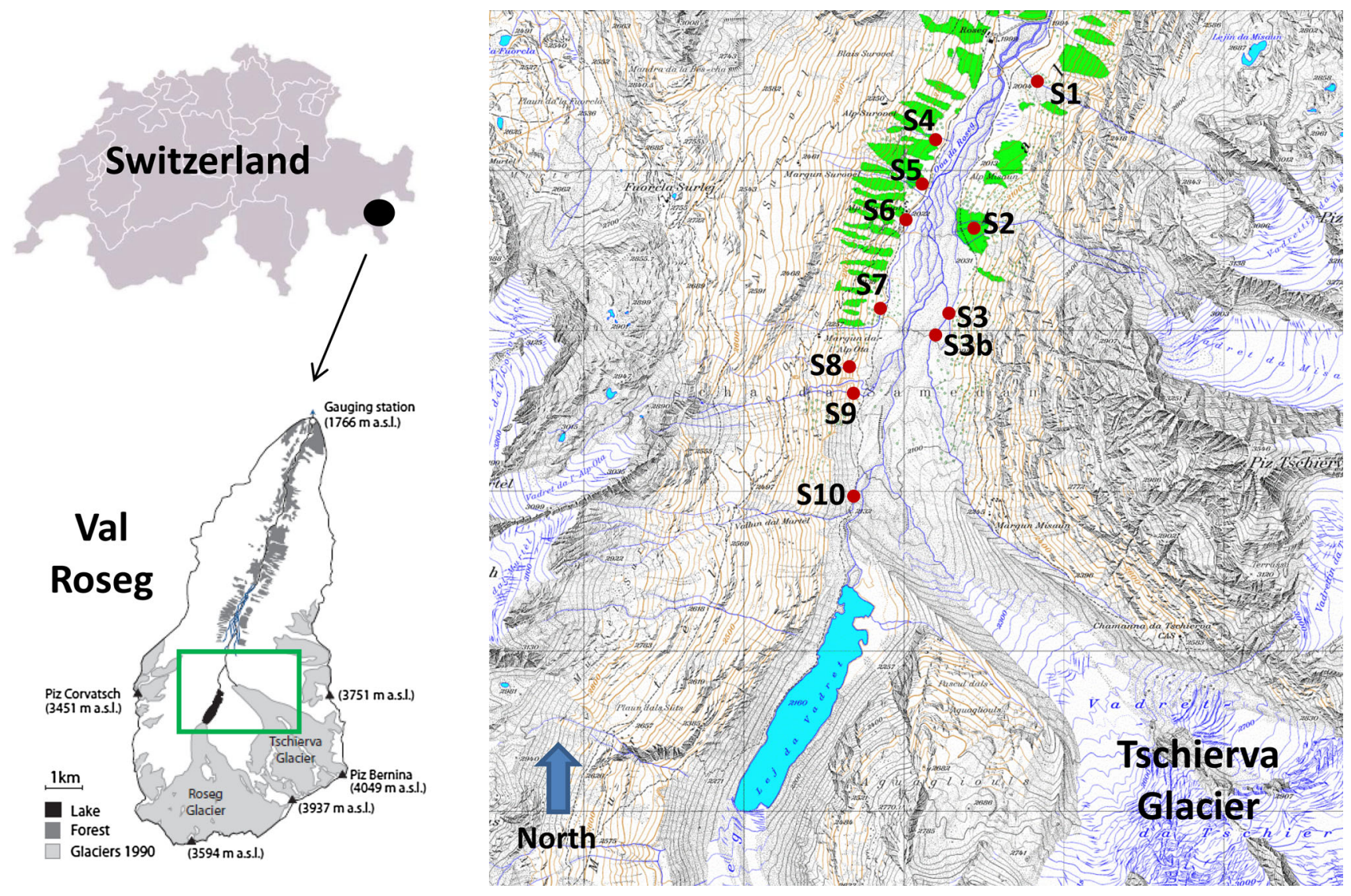

Fig. 1 Map of the Val Roseg catchment in Switzerland showing the floodplain and major tributaries (inset shows boundary of detail map with glacial presence in 1990). Study streams are indicated by labeled symbols (see "Methods" section and Fig. 2 regarding the mapping of

(source to mouth) with the GPS receiver. The streams were inspected at $c a$. bi-weekly intervals along two elevational isoclines during the study period to check for intermittency (seasonal, and diel on a particular inspection day); field mapping typically required at least 2 days on each visit.

The GPS field data were post-processed using the software package MapSource ${ }^{\mathrm{TM}} 6.0$ (Garmin ${ }^{\circledR}$ International Inc., Olathe, KS, USA). Afterwards, the spatial data were exported as shape files into the Geographic Information System (GIS) $\operatorname{ArcView}^{\circledR} 3.2$ and $\operatorname{ArcGIS}^{\circledR} 9$ and the stream network was digitized as line coverages. Further analyses were performed using only these coverages. Some editing was needed to remove or adjust the erroneous position of streams due to low GPS accuracy, stream drying, and other mapping issues. Using orthophotos, pixel maps (map image into digital form at 1:25,000 scale), vector 25 (Swisstopo digital grid at 1:25,000 scale), $\operatorname{ArcView}^{\circledR} 3.2$ and ArcGIS $^{\odot} 9$, the routes of the $c a .85 \mathrm{~km}$ of digitized streams were corrected and standardized. The final maps only included streams that carried water at least once during the study period during field mapping or were shown on the topographic maps. these streams) and green areas show areas with side-slope vegetation. Map reproduced with permission of the Swiss Federal Office of Topography

Each stream was categorized as permanent, intermittent or dry. Permanent streams always carried water along the entire stream course. Dry streams were always dry along the entire course, and intermittent streams carried water either along the entire course or in subreaches at least once. This categorization is valid only for the study period (early May through end August 2005 when surface flows are highest in Alpine areas due to snow/ice melt), as permanent streams may have been dry prior to the first mapping and no data were collected in autumn. For example, Malard et al. (2005) reported that the lowermost section of some tributaries to the lower floodplain were dry from January to March in most years.

\section{Physico-chemical characterization}

Ten headwaters were selected initially for characterization of physico-chemistry (Fig. 1). The selection occurred before having mapping results, thus the water source of most streams was unknown prior to selection. Two headwaters (S1, S2) had water source contributions by meltwater of hanging glaciers. One stream separated near the 
source and S3 was used for characterizing physcio-chemistry, whereas both channels ( $\mathrm{S} 3, \mathrm{~S} 3 \mathrm{~b}$ ) were used in the quantification of periphyton biomass and sediment respiration (see below). Streams S1, S2, and S3 (including S3b) flowed off east-facing side-slopes, whereas streams S4, S5, S6, S7, S8, S9 and S10 flowed off west-facing side-slopes in the valley. Stream S5 ended up being dry the entire study period and was excluded from all analyses except for the channel network mapping described above. Thus, 9 streams with surface flow during the study were used to characterize physico-chemical properties (S1-S10, excluding S3b and S5).

Sampling took place every 2 weeks during the study period. Electrical conductivity $\left(20^{\circ} \mathrm{C}\right.$ reference temperature) and water temperature (spot measurements) were measured with a conductivity meter (WTW LF320, Germany), $\mathrm{pH}$ with a WTW $\mathrm{pH} 330 \mathrm{i} \mathrm{pH}$ meter, and turbidity with a Cosmos turbidity meter (Züllig AG, Switzerland). Discharge was measured on each sample date at a site using the salt dilution method (Gordon et al. 1992). Water temperature was recorded hourly with temperature loggers (StowAway and StowAway TidbiT, Onset Computer Corp., USA and Minilog, Vemco Ltd, Canada), although loggers failed in streams S1, S4, and S6. Surface water was collected in 1-L polyethylene bottles, filtered (Whatman GF/F filters, $0.7 \mu \mathrm{m}$ ) and stored at $4{ }^{\circ} \mathrm{C}$ for laboratory analysis.

For the lab-processed water samples, calcium $(\mathrm{Ca})$, magnesium $(\mathrm{Mg})$, sodium $(\mathrm{Na})$, potassium $(\mathrm{K})$, sulphate $\left(\mathrm{SO}_{4}\right)$, and chloride $(\mathrm{Cl})$ were analyzed by Ion Chromatography. Silica $\left(\mathrm{SiO}_{2}\right)$ was quantified by the heteropoly blue method (APHA 1989). Nitrite $\left(\mathrm{NO}_{2}-\mathrm{N}\right)$ was measured by spectrophotometry (Hitachi U-1000 Spectrophotometer) after diazotizing with sulphanilamide and coupling with $\mathrm{N}$-(1-napthyl)-ethylenediamine (Rodier 1996). Ammonium $\left(\mathrm{NH}_{4}-\mathrm{N}\right)$ was measured with the indophenol-blue method. Nitrate $\left(\mathrm{NO}_{3}-\mathrm{N}\right)$ was quantified by the automated hydrazine reduction method (Downes 1978). Dissolved nitrogen (DN) was quantified as $\mathrm{NO}_{3}-\mathrm{N}$ after all nitrogen forms had been oxidized to nitrate with $\mathrm{K}_{2} \mathrm{~S}_{2} \mathrm{O}_{8}$ and $\mathrm{NaOH}$ at $121{ }^{\circ} \mathrm{C}$ (Ebina et al. 1983). Phosphate $\left(\mathrm{PO}_{4}-\mathrm{P}\right)$ was analyzed according to the molybdenum blue method. Dissolved phosphorus (DP) was determined as $\mathrm{PO}_{4}-\mathrm{P}$ after digestion with $\mathrm{K}_{2} \mathrm{~S}_{2} \mathrm{O}_{8}$ and $\mathrm{NaOH}$ at $121{ }^{\circ} \mathrm{C}$ (Ebina et al. 1983).

For particulate organic carbon (POC), particulate nitrogen (PN) and particulate phosphorus (PP), 250-ml aliquots of stream water were filtered through Whatman GF/F filters. For $\mathrm{PN}$ and PP, filters were digested with $\mathrm{K}_{2} \mathrm{~S}_{2} \mathrm{O}_{8}$ and $\mathrm{NaOH}$ at $121{ }^{\circ} \mathrm{C}$ (Ebina et al. 1983) and oxidized to nitrate and hydrolysed to ortho-phosphate. Further analysis was based on the methods described for nitrate and phosphate. POC was determined by ashing filters at $880{ }^{\circ} \mathrm{C}$ and subsequently removing the developing $\mathrm{CO}_{2}$ with nitrogen and quantified using a Fuji electric infrared gas analyser
(Uehlinger et al. 1984). Dissolved organic carbon (DOC) was measured by acidifying the samples with $\mathrm{HCl}$, thereby the inorganic carbon was released as $\mathrm{CO}_{2}$. The remaining organic carbon was burned at $680^{\circ} \mathrm{C}$ and the emerging $\mathrm{CO}_{2}$ was analysed by non-dispersal IR gas analysis (Shimadzu TOC-5000A Analyser). For total inorganic carbon (TIC) analysis, water samples were enclosed in an IC reaction container and acidified with phosphoric acid. Carrier gas was bubbled through the sample and took along the $\mathrm{CO}_{2}$, which was analysed as described for DOC.

\section{Periphyton and transported organic matter (seston/drift)}

Recall that streams for the measures below, including respiration and sediment organic matter, were selected prior to having results on water source inputs. In five study streams (S3 and S3b, S7, S8, S10), 10 stones (cobble size) were collected at random in each stream on five dates between early May and late August 2005 for quantification of periphyton. Stones were transferred in plastic bags to the laboratory and stored at $-25{ }^{\circ} \mathrm{C}$ until analysis. In the laboratory, periphyton was removed from the surface of each stone by brushing with a metal brush and rinsing with water. From the resulting suspension, two sub-samples were taken (10-30 ml each) and filtered (Whatman GF/F filters, $0.7 \mu \mathrm{m}$ ) to determine the organic matter content as ash-free dry mass (AFDM) and chlorophyll a per $\mathrm{m}^{2}$ (after Uehlinger 1991). To determine AFDM, respective filters were dried at $60{ }^{\circ} \mathrm{C}$, weighed, burned at $500{ }^{\circ} \mathrm{C}$ for $4 \mathrm{~h}$, and reweighed. For chlorophyll a, each respective filter was extracted in $6 \mathrm{ml}$ hot ethanol $\left(90 \%\right.$ at $\left.70{ }^{\circ} \mathrm{C}\right)$ and chlorophyll determined spectrophotometrically according to Meyns et al. (1994).

Seston/drift (transported organic matter) samples $(n=4)$ were collected on each sampling date in 4 study streams (S2, S7, S8, S10) using a 1-m long $100-\mu \mathrm{m}$ mesh nylon drift net. Sampling lasted 3-10 min, depending on net clogging by fine particles. Flow velocity (Mini Air 2, Schiltknecht, Switzerland) was measured at the net opening to standardize seston samples to volume of water (after Hieber 2002). Streams S7 and S10 had samples collected at an upstream (at treeline) and downstream site (entry in floodplain) to test whether seston/drift increased longitudinally along tributary streams. Samples were stored at $-25{ }^{\circ} \mathrm{C}$ until processed. For processing, seston samples were separated into coarse $(>1 \mathrm{~mm}$ : CPOM) and fine material $(<1 \mathrm{~mm}$ : FPOM) using a $1-\mathrm{mm}$ sieve. Prior to sieving, all macroinvertebrates were picked from each sample. Macroinvertebrates and organic matter fractions were filtered (Whatman GF/F filters, $0.7 \mu \mathrm{m}$ ), dried at $60{ }^{\circ} \mathrm{C}$, weighed, ashed at $500{ }^{\circ} \mathrm{C}$ for $4 \mathrm{~h}$ and reweighed to calculate AFDM. 


\section{Hyporheic sediment respiration and organic matter}

Respiration rates of hyporheic sediments were measured in 5 study streams (S3, S3b, S7, S8, S10) as oxygen consumption in the uppermost bed sediments according to the method of Jones (1995). In each stream, 4 replicate samples were taken on 4 sampling dates between May and August 2005. The periphyton-coated top layer at the surface of the streambed was removed before hyporheic sediment was collected to a depth of $20 \mathrm{~cm}$. Sediment particles $>8 \mathrm{~mm}$ were excluded by sieving (after Naegeli et al. 1995). Cylindrical plexiglas chambers (5.3-cm diameter, $30-\mathrm{cm}$ long) were half-filled with these sediments and half with stream water. Subsequently, chambers were inverted several times (to remove air trapped in the sediment) and the oxygen concentration and temperature were measured with an oxygen meter (WTW Oxi340i, Weilheim, Germany) before sealing the chambers with a rubber stopper. Sealed chambers were wrapped in black plastic and incubated in each respective stream for 4-8 h. After incubation, chambers were again inverted three times before measuring final dissolved oxygen concentrations and temperature.The contents of each chamber (water and sediments) were transferred to plastic storage bags, frozen at $-25^{\circ} \mathrm{C}$ and returned to the laboratory for analysis of sediment particulate organic matter (POM) (see below).

To obtain hyporheic respiration rates $\left(\mathrm{g} \mathrm{O}_{2} \mathrm{~h}^{-1} \mathrm{~kg}^{-1}\right.$ sediment), differences in oxygen concentration of each chamber was divided by the corresponding incubation time (h) and normalized by sediment weight (kg sediment). To compare hyporheic respiration values of streams with different temperature regimes, hyporheic respiration was normalized to a reference temperature of $15^{\circ} \mathrm{C}\left(\mathrm{R}_{\left(15{ }^{\circ} \mathrm{C}\right)}\right)$ as follows:

$\mathrm{R}_{\left(15^{\circ} \mathrm{C}\right)}=\mathrm{R}_{(\mathrm{T})} \times 1.072^{-\left(\mathrm{T}-15^{\circ} \mathrm{C}\right)}$

where $R_{(T)}$ is the measured respiration rate $\left(\mathrm{g} \mathrm{O}_{2} \mathrm{~h}^{-1} \mathrm{~kg}^{-1}\right.$ sediment) at the sampled field temperature $\left({ }^{\circ} \mathrm{C}\right)$ (see Naegeli et al. 1995, Doering et al. 2013).

Sediments from each chamber were analyzed for particulate organic matter (POM) in different size classes. POM ( $n=4$ per date and site) was separated into two fractions: loosely attached POM (LPOM) and strongly attached POM (SPOM) to sediment grains. LPOM was associated with dead organic matter (detritus) and was elutriated with water, whereas SPOM primarily consisted of biofilms attached to sediments (Naegeli et al. 1995). LPOM was rinsed from sediments and separated into two size fractions: $<0.063 \mathrm{~mm}$ and $>0.063 \mathrm{~mm}$. The remaining sediments of the SPOM fraction were separated (wet sieving) into four size classes $(<0.063 \mathrm{~mm}$, $0.063-0.25 \mathrm{~mm}, 0.25-1 \mathrm{~mm}, 1-8 \mathrm{~mm})$. The ash-free dry mass was determined for each LPOM and SPOM size fraction. The smallest size POM fraction $(<0.063 \mathrm{~mm})$ was first sub-sampled and then filtered through pre-ashed (at $500{ }^{\circ} \mathrm{C}$ for $3 \mathrm{~h}$ ) glass fiber filters (Millipore APFF; 0.7- $\mu \mathrm{m}$ pore size) before AFDM determination. The organic matter content of each sample (g AFDM kg ${ }^{-1}$ sediment) was calculated by summing the AFDM values of the different fractions and dividing by the sample weight.

\section{Data analysis}

Data generated from the mapping analysis were summarized to compare the extent of different types (permanent, dry, intermittent) of tributary streams in comparison to total channel lengths and relative change in the proportion (percentages) of stream types over the period of study. The physico-chemical data were assessed using principal components analysis (PCA, varimax rotation) on $\log (\mathrm{X}+1)$ transformed data to group streams having similar water source characteristics. Repeated measures ANOVA, using $\log (\mathrm{X}+1)$ transformed data to improve normality and heteroscedasticity, tested for differences in periphyton biomass, seston and sediment respiration among streams and dates, followed by Tukey's posthoc test when significant differences were found (Zar 1984). Pearson correlation was used to determine significant relationships between selected variables such as respiration and organic matter components (following Doering et al. 2013).

\section{Results}

\section{Stream network mapping}

The total stream length in the $49.5 \mathrm{~km}^{2}$ catchment study area was $85.3 \mathrm{~km}$ of tributary and other floodplain channels (Fig. 2). The total lengths of tributary streams, excluding floodplain channels, that were intermittent, permanent, or dry during the study period (early May to end August) were $50.7 \mathrm{~km}(77 \%), 8.9 \mathrm{~km}(13.5 \%)$, and $6.2 \mathrm{~km}(9.5 \%)$, respectively. In the active floodplain itself, various channels comprised $37 \%(19.5 \mathrm{~km})$ of the overall stream network. Overall, about $90 \%(76.8 \mathrm{~km})$ of the drainage network in the catchment study area was intermittent.

During the study period in 2005 (125 days in total), air temperatures were low in May such that glacier melt remained relatively limited and no surface water flowed at the terminus of most glacial-fed tributaries. About $38 \%$ of the channel network was dry during this period, whereas about $62 \%$ had surface water. Towards summer as air temperatures increased, the length of dry channels 


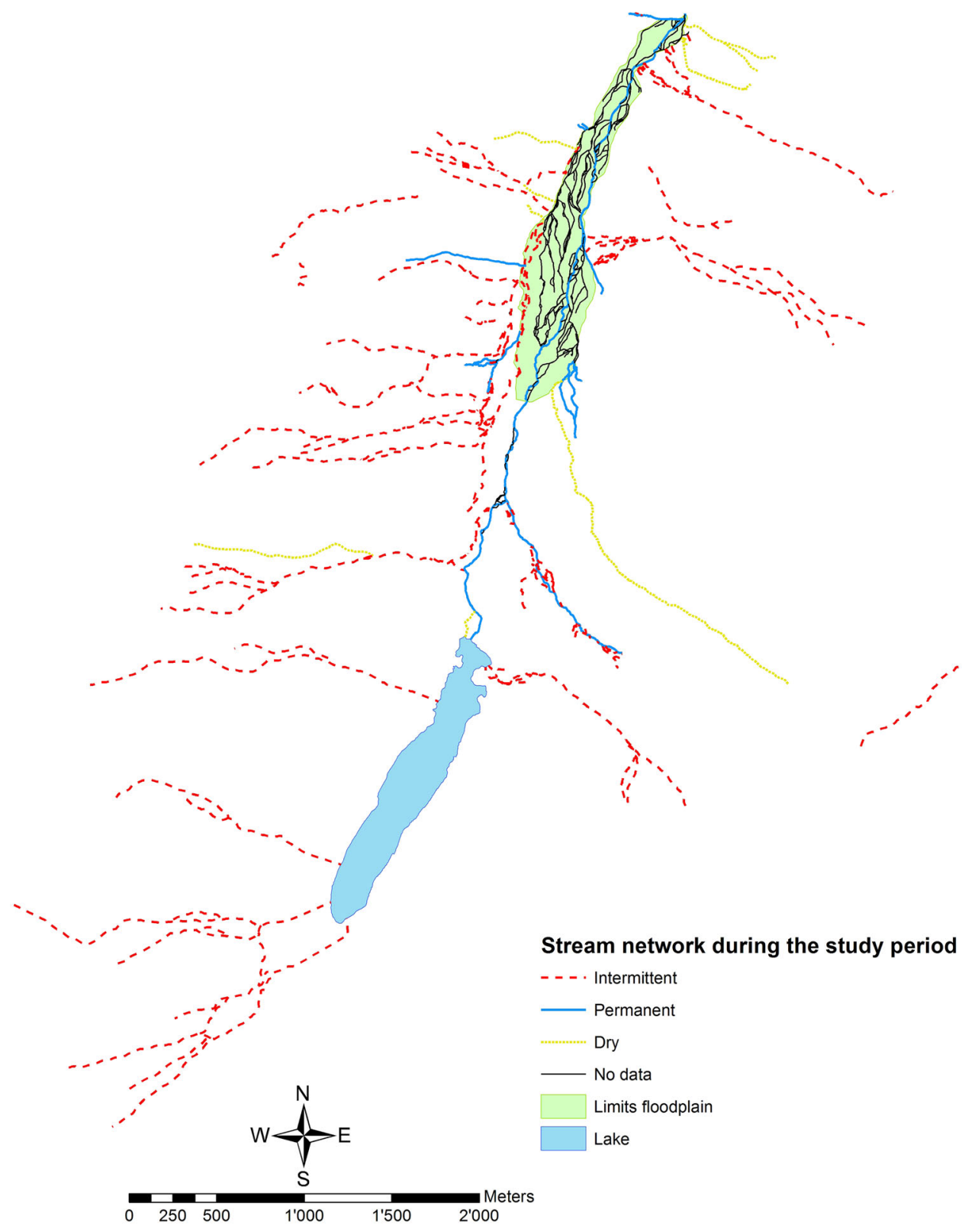

Fig. 2 GIS based map of the fluvial network in the Val Roseg showing the permanent, intermittent, and dry streams at the time of the study (2005)

decreased continuously from $14 \%$ in late May to $0 \%$ at the late July to mid-August. For instance, the flow period among the 10 streams used in the ecological part of the study ranged from 0 days for $\mathrm{S} 5$ to $>100$ days for S3, S3b, S6, S7, S8, S9, and S10. Surface flow started the latest in the two glacial streams (S1, S2). There also was a diel cycle in flow with no surface water at S1 and S2 from late evening to early morning when glacial melt was minimal or even lacking and relatively high discharge during the day from increased glacial melt. The change between surfacewater and dry stages could occur within a couple of hours as glacial water inputs increased at dawn and decreased at dusk (authors, personal observation).

\section{Physico-chemical characteristics}

A principal components analysis (PCA) grouped the 9 study streams into three clusters based on physico-chemistry differences (Fig. 3). These groups consisted of S1 and S2 having a predominant source of water from hanging glaciers (refered as glacial ' $\mathrm{g}$ ' streams below), streams S3 and S9 with an apparent groundwater contribution (refered as groundwater ' $\mathrm{gw}$ ' streams), and the other streams having a potential mix of water sources (refered as mixed 'mix' streams). The first two factors of the PCA explained $68 \%$ of the total variation in physico-chemical measures between streams. PCA factor-1 was associated with electrical conductivity, 


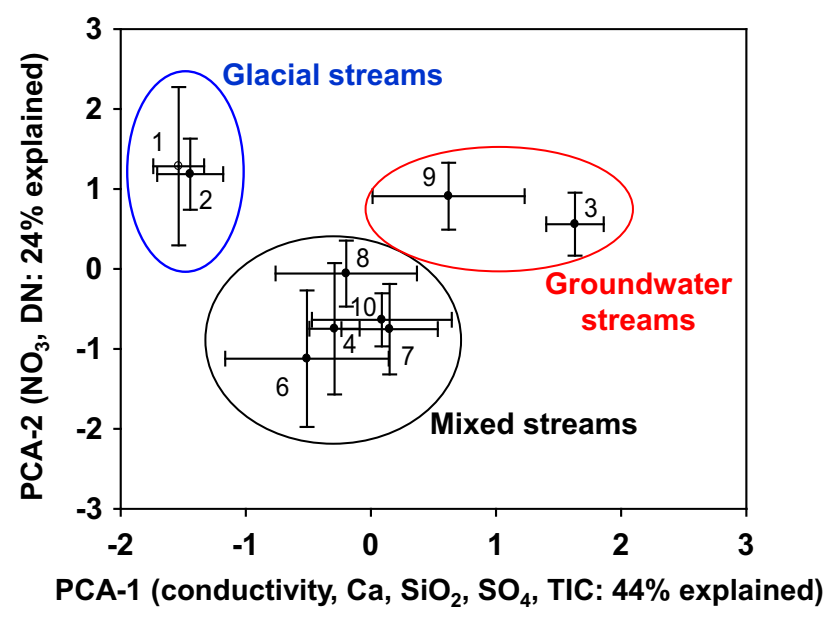

Fig. 3 Scatterplot of the PCA results based on physico-chemical measures recorded at 9 study streams (as stream number in plot, stream S5 was dry and not included). Data plotted show mean and standard deviation for each stream based on biweekly samples between early May and late August $2005(n=8)$. Axis labels represent parameters with a factor loading $>0.70$, and parameters were positively related to each axis. PCA factors- 1 and -2 explained 44 and $24 \%$ of the total variation, respectively

calcium, silica, sulphate and total inorganic carbon (TIC), whereas PCA factor-2 was associated with dissolved nitrogen and nitrate. In general, glacial streams $\left(\mathrm{S} 1_{\mathrm{g}}, \mathrm{S} 2_{\mathrm{g}}\right)$ had lowest mean values and groundwater streams highest mean values along PCA-1, whereas mixed sites had lowest mean values along PCA-2. Further, glacial streams $\left(\mathrm{S} 1_{\mathrm{g}}, \mathrm{S} 2_{\mathrm{g}}\right)$ showed high variation for $\mathrm{NO}_{3}-\mathrm{N}$ and $\mathrm{DN}$, and low variation for electrical conductivity, ionic composition and TIC, whereas the opposite was true for groundwater streams. In contrast, mixed streams had relatively high variation in measures of both factors.

Mean discharge among study streams ranged from 3.9 to $48.8 \mathrm{~L} / \mathrm{s}$ (Table 1). Mean temperature among streams ranged from 1.8 to $6.9^{\circ} \mathrm{C}$ and within stream variation (CV) ranged from 16 to $87 \%$ (Table 1). Electrical conductivity was lowest in glacial streams $\left(\leq 18 \mu \mathrm{S} \mathrm{cm}^{-1}\right)$ and highest in groundwater streams $\left(48-66 \mu \mathrm{S} \mathrm{cm}^{-1}\right)$ with overall low within stream variation during the study period (CV range $=10-30 \%$ ). Turbidity was generally low, on average being less than 10 NTU, although higher mean values were found at $S 2_{g}$ (12.1 NTU) and $\mathrm{S} 9_{\text {mix }}$ (21.4 NTU). Variation within streams in turbidity $(\mathrm{CVs})$ ranged from $10 \%\left(\mathrm{~S} 4_{\text {mix }}\right)$ to $127 \%\left(\mathrm{~S} 7_{\text {mix }}\right)$. Mean $\mathrm{pH}$ ranged from 6.7 to 7.6 among streams. Mean DOC concentrations were generally low $\left(\leq 1.0 \mathrm{mg} \mathrm{L}^{-1}\right)$ in all streams, but varied (CVs) from 14 to $78 \%$ within streams.

Mean nitrate $\left(\mathrm{NO}_{3}-\mathrm{N}\right)$ concentrations were highest in glacial streams $\left(0.17\right.$ and $\left.0.22 \mathrm{mg} \mathrm{L}^{-1}\right)$, except for groundwater stream $\mathrm{S} 33_{\mathrm{gw}}$ at $0.23 \mathrm{mg} \mathrm{L}^{-1}$ (Table 1). Mean nitrate concentrations were two-fold higher in streams draining the east-side of the valley relative to those draining the valley west side, although two of the three east-side streams were glacial fed. Phosphorus $\left(\mathrm{PO}_{4}-\mathrm{P}\right)$ concentrations were generally low, ranging on average from 0.50 to $1.55 \mu \mathrm{g} \mathrm{L}^{-1}$. Particulate phosphorus concentrations were highest in glacial streams (mean $>8.0 \mu \mathrm{g} \mathrm{L}^{-1}$ ), except for mixed stream $\mathrm{S} 4_{\text {mix }}$ (mean $\left.\mathrm{PP}=9.8 \mu \mathrm{g} \mathrm{L}^{-1}\right)$. Silica $\left(\mathrm{SiO}_{2}\right)$ was lowest in the glacial streams (ca. $1.54 \mathrm{mg} \mathrm{L}^{-1}$ ) and ranged from 2.59 ( $\left.\mathrm{S} 10_{\text {mix }}\right)$ to $4.76 \mathrm{mg} \mathrm{L}^{-1}\left(\mathrm{~S} 3_{\mathrm{gw}}\right)$ in the other headwaters. Lastly, calcium $(\mathrm{Ca})$ ranged from 2.5 in the glacial streams to 4.3-11.2 $\mathrm{mg} \mathrm{L}^{-1}$ in the other study streams (Table 1).

\section{Periphyton and seston/drift}

Periphyton was quantified in streams $\mathrm{S} 3_{\mathrm{gw}}, \mathrm{S} 3 \mathrm{~b}_{\mathrm{gw}}, \mathrm{S} 7_{\text {mix }}$, $\mathrm{S} 8_{\text {mix }}$, and $\mathrm{S} 10_{\text {mix }}$ (see map Fig. 1). In these streams, temporal patterns of periphyton chlorophyll a and AFDM were highly variable (Fig. 4). Levels of chlorophyll a were highest in May for $\mathrm{S} 3 \mathrm{~b}_{\mathrm{gw}}, \mathrm{S} 7_{\text {mix }}$ and $\mathrm{S} 10_{\text {mix }}$, while $\mathrm{S} 3_{\mathrm{gw}}$ and $\mathrm{S}_{\text {mix }}$ had maximal chlorophyll a levels in June (Tukey's test, $p<0.05$ ). Periphyton AFDM had the same pattern as chlorophyll a in $\mathrm{S} 3 \mathrm{~b}_{\mathrm{gw}}, \mathrm{S} 7_{\text {mix }}$ and $\mathrm{S} 8_{\text {mix }}$, whereas $\mathrm{S} 10_{\text {mix }}$ had highest levels in June/July and $\mathrm{S} 3_{\mathrm{gw}}$ peaked in AFDM in August.

Total suspended organic matter (seston/drift) was quantified in streams $\mathrm{S} 2_{\mathrm{g}}, \mathrm{S} 7_{\text {mix }}, \mathrm{S} 8_{\text {mix }}$, and $\mathrm{S} 10_{\text {mix }}$ (see map Fig. 1). Seston/drift was highest in $\mathrm{S} 2_{\mathrm{g}}$ (Tukey's test, $p<0.05$ ), averaging ca. $0.26 \mathrm{mg} \mathrm{AFDM} \mathrm{L}^{-1}$, whereas this value varied between 0.03 and $0.09 \mathrm{mg} \mathrm{AFDM} \mathrm{L}^{-1}$ at the other streams (Fig. 5). The FPOM fraction represented between 33 and $76 \%$ of the total seston/drift in the streams. The CPOM fraction varied between 14 and $43 \%$ of the total seston/drift, whereas the AFDM of invertebrates in the drift varied between 7 and $24 \%$. In streams $\mathrm{S} 7_{\text {mix }}$ and $\mathrm{S} 10_{\text {mix }}$, where seston/drift was sampled at an upstream and downstream location, levels were always highest at the downstream site. For example, the mean total seston/drift at $\mathrm{S} 7_{\text {mix }}$ upstream site was $0.02 \mathrm{mg} \mathrm{AFDM} \mathrm{L}^{-1}$ and was $0.07 \mathrm{mg} \mathrm{AFDM} \mathrm{L}^{-1}$ at the downstream site (data not shown). Here, the percentage CPOM (43-37\%) and invertebrates (24-11\%) decreased in seston/drift, and percentage FPOM (33-52\%) increased, between the upstream and downstream site.

\section{Hyporheic sediment respiration}

Hyporheic sediment respiration was quantified at streams $\mathrm{S} 3_{\mathrm{gw}}, \mathrm{S} 3 \mathrm{~b}_{\mathrm{gw}}, \mathrm{S} 7_{\text {mix }}, \mathrm{S} 8_{\text {mix }}, \mathrm{S} 10_{\text {mix }}$ (see map Fig. 1). A general decrease in hyporheic sediment respiration (temperature corrected at $15^{\circ} \mathrm{C}$ ) was observed over time in all streams with maximal values in May and June, and values decreasing in July and August (Fig. 6). Hyporheic sediment respiration was highest at $\mathrm{S} 10_{\text {mix }}$ with $0.126 \mathrm{mg} \mathrm{O}_{2} \mathrm{~h}^{-1} \mathrm{~kg}^{-1}$ sediment 
Table 1 Means, standard deviations (SD), and coefficients of variation (CV as \%) of selected physico-chemical parameters at the study streams, except stream S5 which was dry ( $n=8$ : May-August 2005)

\begin{tabular}{|c|c|c|c|c|c|c|c|c|c|c|c|}
\hline Stream \# & Source & $\begin{array}{l}\text { Discharge } \\
\mathrm{L} \mathrm{s}^{-1}\end{array}$ & $\begin{array}{l}\text { Temperature } \\
{ }^{\circ} \mathrm{C}\end{array}$ & $\begin{array}{l}\text { Conductivity } \\
\mu \mathrm{S} \mathrm{cm}{ }^{-1} @ 20{ }^{\circ} \mathrm{C}\end{array}$ & $\begin{array}{l}\text { Turbidity } \\
\text { NTU }\end{array}$ & $\begin{array}{l}\mathrm{NO}_{3}-\mathrm{N} \\
\mathrm{mg} \mathrm{L}^{-1}\end{array}$ & $\begin{array}{l}\mathrm{PO}_{4}-\mathrm{P} \\
\mu \mathrm{g} \mathrm{L}^{-1}\end{array}$ & $\begin{array}{l}\mathrm{PP} \\
\mu \mathrm{g} \mathrm{L}\end{array}$ & $\begin{array}{l}\text { DOC } \\
\mathrm{mg} \mathrm{L}^{-1}\end{array}$ & $\begin{array}{l}\mathrm{SiO}_{2} \\
\mathrm{mg} \mathrm{L}^{-1}\end{array}$ & $\begin{array}{l}\mathrm{Ca} \\
\mathrm{mg} \mathrm{L}\end{array}$ \\
\hline S1 & Glacial & & & & & & & & & & \\
\hline Mean & & 3.9 & 5.0 & 13.4 & 7.9 & 0.22 & 0.50 & 7.8 & 0.26 & 1.48 & 2.5 \\
\hline SD & & 5.3 & 4.4 & 2.2 & 4.4 & 0.10 & 0.00 & 6.4 & 0.05 & 0.11 & 0.0 \\
\hline $\mathrm{CV}$ & & 140 & 87 & 16 & 56 & 46 & 0 & 82 & 20 & 7 & 0 \\
\hline S2 & Glacial & & & & & & & & & & \\
\hline Mean & & 48.8 & 3.8 & 18.1 & 12.1 & 0.17 & 0.72 & 9.2 & 0.24 & 1.58 & 2.5 \\
\hline SD & & 62.8 & 1.1 & 3.8 & 9.9 & 0.08 & 0.48 & 5.1 & 0.14 & 0.27 & 0.0 \\
\hline $\mathrm{CV}$ & & 130 & 28 & 21 & 82 & 46 & 68 & 55 & 60 & 17 & 0 \\
\hline S3 & Ground & ater & & & & & & & & & \\
\hline Mean & & 7.8 & 3.7 & 66.3 & 1.7 & 0.23 & 1.10 & 2.8 & 0.32 & 4.76 & 11.2 \\
\hline SD & & 6.2 & 0.6 & 10.1 & 1.4 & 0.03 & 1.42 & 1.7 & 0.22 & 0.24 & 2.2 \\
\hline $\mathrm{CV}$ & & 80 & 16 & 15 & 79 & 13 & 129 & 60 & 71 & 5 & 19 \\
\hline S9 & Ground & ater & & & & & & & & & \\
\hline Mean & & 7.0 & 6.1 & 48.7 & 21.4 & 0.19 & 1.51 & 4.8 & 0.20 & 3.54 & 9.1 \\
\hline SD & & 1.7 & 2.8 & 10.6 & 20.1 & 0.03 & 0.98 & 3.0 & 0.12 & 0.46 & 1.6 \\
\hline $\mathrm{CV}$ & & 20 & 43 & 22 & 94 & 15 & 65 & 62 & 59 & 14 & 17 \\
\hline S6 & Mixed & & & & & & & & & & \\
\hline Mean & & 4.0 & 6.9 & 31.6 & 1.1 & 0.08 & 0.59 & 2.0 & 1.00 & 2.71 & 4.3 \\
\hline SD & & 1.9 & 2.4 & 8.7 & 1.3 & 0.08 & 0.25 & 1.5 & 0.40 & 0.27 & 2.7 \\
\hline $\mathrm{CV}$ & & 50 & 34 & 27 & 115 & 101 & 43 & 77 & 40 & 10 & 62 \\
\hline S7 & Mixed & & & & & & & & & & \\
\hline Mean & & 4.0 & 6.4 & 38.9 & 4.9 & 0.10 & 0.50 & 1.5 & 0.35 & 4.16 & 6.5 \\
\hline SD & & 1.9 & 2.8 & 7.2 & 6.2 & 0.05 & 0.00 & 0.9 & 0.18 & 0.40 & 0.8 \\
\hline $\mathrm{CV}$ & & 50 & 44 & 18 & 127 & 52 & 0 & 60 & 52 & 10 & 12 \\
\hline S8 & Mixed & & & & & & & & & & \\
\hline Mean & & 22.8 & 6.0 & 36.4 & 10.0 & 0.14 & 1.00 & 3.8 & 0.29 & 3.03 & 5.9 \\
\hline SD & & 19 & 2.8 & 8.7 & 9.3 & 0.03 & 0.79 & 2.7 & 0.22 & 0.55 & 1.9 \\
\hline $\mathrm{CV}$ & & 80 & 46 & 24 & 92 & 24 & 79 & 72 & 76 & 18 & 32 \\
\hline S10 & Mixed & & & & & & & & & & \\
\hline Mean & & 36.5 & 6.2 & 45.4 & 2.8 & 0.10 & 0.68 & 3.1 & 0.43 & 2.59 & 8.5 \\
\hline SD & & 20.8 & 3.5 & 13.7 & 1.9 & 0.03 & 0.50 & 1.6 & 0.34 & 0.48 & 2.3 \\
\hline $\mathrm{CV}$ & & 60 & 57 & 30 & 60 & 36 & 74 & 52 & 78 & 18 & 27 \\
\hline
\end{tabular}

Source Category was based on the PCA results

in June and lowest at $\mathrm{S}_{\text {mix }}$ with $0.005 \mathrm{mg} \mathrm{O}_{2} \mathrm{~h}^{-1} \mathrm{~kg}^{-1}$ sediment in July. Mean respiration rates among streams ranged from 0.025 to $0.062 \mathrm{mg} \mathrm{O}_{2} \mathrm{~h}^{-1} \mathrm{~kg}^{-1}$ sediment. Hyporheic sediment respiration varied substantially among streams as well as within streams among dates. There were significant relationships $(p<0.05)$ between hyporheic sediment respiration and the AFDM of LPOM $<0.063 \mathrm{~mm}$ $(r=0.51), \quad \mathrm{SPOM}<0.063 \mathrm{~mm} \quad(r=0.62), \quad$ and total AFDM $(r=0.47)$. Sediment organic matter declined slightly during the study period in the study streams, and the amount significantly differed among streams $\left(\mathrm{F}_{4,15}=23.9, p<0.001\right)$. The strongly attached organic matter (SPOM) was the dominant POM fraction in all streams, exceeding loosely attached organic matter (LPOM) by about 8 fold.

\section{Discussion}

\section{Extent of intermittent streams in the catchment}

Mapping results showed that intermittent streams dominated the drainage network of this high elevation alpine catchment, comprising up to $90 \%$ of the channel network during the study period. Except for the outlet of the proglacial Roseg lake and the glacial stream below the 


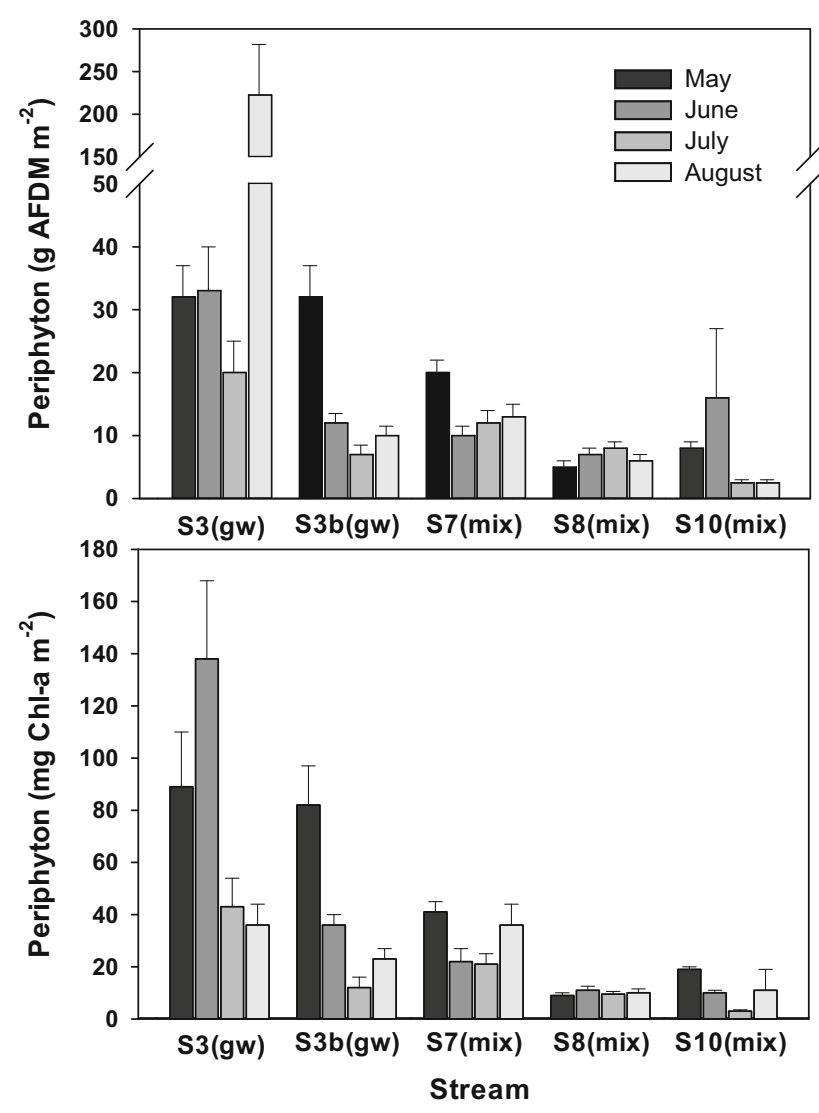

Fig. 4 Mean $(+\mathrm{SE}, n=4)$ periphyton biomass $\left(\mathrm{g}\right.$ AFDM m $\left.{ }^{-2}\right)$ and chlorophyll a $\left(\mathrm{mg} \mathrm{m}^{-2}\right)$ at 5 study streams in Val Roseg on 4 dates between May and August 2005. In label, $g w$ groundwater stream, mix mixed stream (see text)

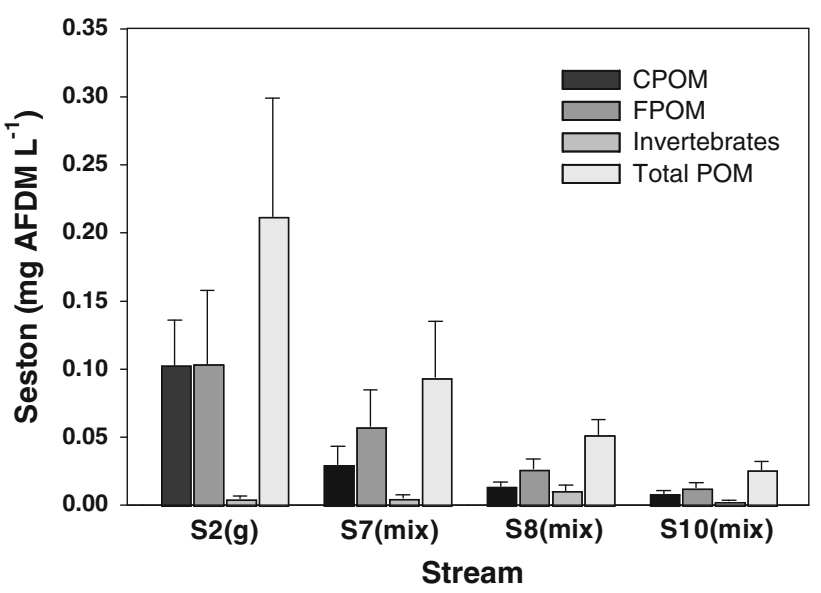

Fig. 5 Mean $(+$ SE, $n=16)$ CPOM, FPOM, invertebrates and total seston concentrations (AFDM mg L ${ }^{-1}$ ) at 4 study streams in $\mathrm{Val}$ Roseg. Samples were collected on 4 dates between May and August 2005 at each stream with pooled data shown in graph. In label, $g$ glacial stream, mix mixed stream (see text)

Tschierva glacier, most floodplain tributaries were presumably intermittent as well, at least from January to March (Malard 2003; Malard et al. 2005). Other studies

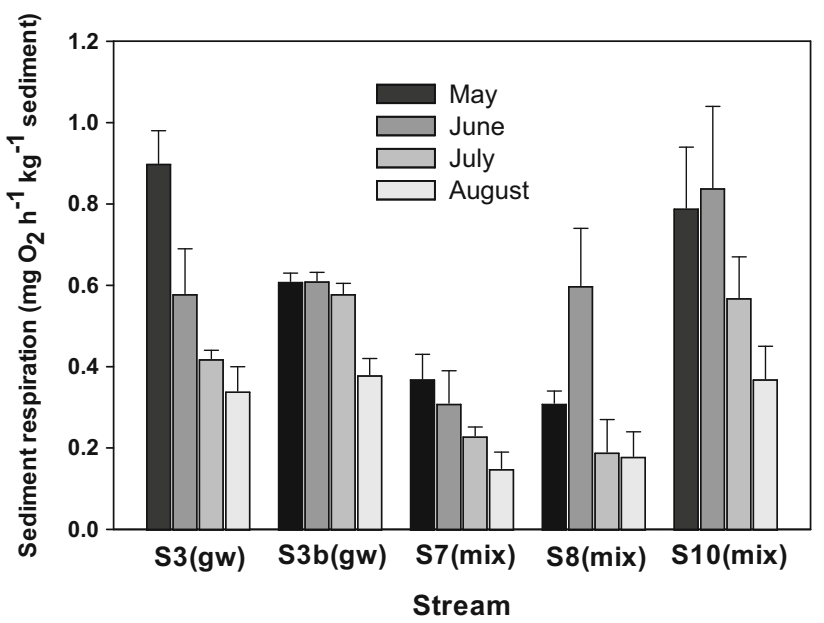

Fig. 6 Mean $(+\mathrm{SE}, n=4)$ hyporheic respiration (temperature corrected as $\mathrm{mg} \mathrm{O}_{2} \mathrm{~h}^{-1} \mathrm{~kg}^{-1}$ sediment, $T=15^{\circ} \mathrm{C}$ ) at 5 study streams in Val Roseg on 4 dates between May and August 2005. In label, $g w$ groundwater stream, mix mixed stream (see text)

also showed that intermittent channels form a high proportion $(>60 \%)$ of the channel system in other alpine glacial catchments (e.g. Robinson and Matthaei 2007). For example, comprehensive studies in the upper Roseg valley showed that between 1997/1998 and 1999/2000 about $75 \%$ of the glacial floodplain channels were intermittent (Tockner et al. 1997; Zah et al. 2001, 2003; Malard et al. 2005). These results are in line with other studies of intermittent streams repesenting substantial proportions of drainage networks (Buttle et al. 2012; Fritz et al. 2013). The present study supports the view that intermittent streams are a typical feature of drainage networks in alpine catchments where flow is strongly seasonal and aquifers are relatively shallow (Malard et al. 2005; Langston et al. 2011). Additional research is needed on characterizing the hydrology and flow sources of alpine intermittent streams, especially in light of ongoing rapid glacial recession.

The process of continuous and accelerated glacier melting, and shifts in precipitation patterns (IPCC 2014), in high alpine environments suggests the channel network of intermittent streams could change temporally and actually increase in extent, thereby affecting alpine floodplains and downstream waters (Robinson et al. 2003, Alexander et al. 2007, Bocchiola 2014). Intermittent channels are important for creating and maintaining habitat heterogeneity (Gasith and Resh 1999; Lake 2003) and strongly influence downstream ecosystems biologically, chemically and physically (Reid and Ziemer 1994; Stanley and Boulton 1995; Gasith and Resh 1999; Lake 2003; Battin et al. 2008). In the Val Roseg, most studies on intermittent streams have been conducted only in the active floodplain (Tockner et al. 1997; Zah et al. 2001; Malard 2003; Tockner and Malard 2003; Malard et al. 2005), and did not consider intermittent 
headwater streams. Because of the high abundance of intermittent streams found in this study, and intermittent headwaters in general (Fritz et al. 2013), further studies should give more importance to these ecosystems (sensu Datry et al. 2014), especially in respect to seasonal expansion-contraction dynamics as documented for stream networks in various alpine floodplains (Malard et al. 2005, Robinson and Matthaei 2007).

\section{General ecological characteristics of alpine headwaters}

The 9 streams examined in respect to physico-chemistry revealed three general stream types and were mainly classified by seven parameters: $\mathrm{NO}_{3}-\mathrm{N}, \mathrm{DN}$, conductivity, TIC, $\mathrm{SiO}_{2}, \mathrm{SO}_{4}$, and $\mathrm{Ca}$. Streams refered to as 'glacial' streams had the highest nitrogen concentrations but low concentrations of major ions and TIC, as well as low electrical conductivity. Streams fed by glacial/snow melt typically have higher nitrogen concentrations and lower conductivities than other stream types in glacial catchments (Robinson and Matthaei 2007; Rutter et al. 2011; Perrot et al. 2014; Sertic et al. 2015). The flow period for glacial streams was the shortest and diurnal variation in discharge was highest among the headwater streams examined (see Magnusson et al. 2014), whereas seasonal flow variation was in the same range as for 'mixed' streams. Temperature varied over a wide range ( $\left.\min / \max : 0.98,11.6^{\circ} \mathrm{C}\right)$ among streams, and can be explained by the warming of meltwater along the distance it flows from the glacier to the floodplain margin, where the temperature loggers were located. High thermal heterogeneity is a common feature among streams in alpine glacial catchments (Robinson and Matthaei 2007; Brown and Hannah 2008; Tonolla et al. 2010).

Glacial streams are generally characterized as having low temperatures, high turbidity and low concentrations of dissolved ions (e.g. low electrical conductivity) (Milner and Petts 1994; Malard et al. 2000; Slemmons et al. 2013). In this study, in contrast, turbidity was not higher in glacial streams than in the other stream types analyzed but was still closely associated with discharge. The low turbidity ( $<12$ NTU on average) is likely due to the water source in these glacial headwaters coming from hanging glaciers (similar to remnant ice fields) and not active glaciers (NTU often >100; Hieber et al. 2002) as assumed in the conceptual model of Milner and Petts (1994). High nitrogen concentrations in these headwaters were mainly caused by two measurements in July, and indicated that, in addition to glacier meltwater, snow meltwater also contributed to flow. It is known that snow can be rich in nitrogen and two possible sources of nitrogen are the flushing of the snow pack itself or from nitrogen pools in the soil beneath the snow pack (Fountain 1996; Heuer et al. 1999; Malard et al.
2000; Battin et al. 2004, Perrot et al. 2014). For instance, the initial $30 \%$ of the melt volume of snow packs has been shown to contain $50-80 \%$ of the total solutes in snow (Johannessen et al. 1977), thus likely contributing to the high nitrogen values we found in July samples.

Groundwater streams also had high concentrations of nitrogen, but concentrations of major ions and TIC as well as electrical conductivity were elevated compared to glacial streams. This stream type closely matches the definition of krenal streams of Ward (1994) and these headwaters had mostly permanent flow during the study period. For instance, the discharge regime was relatively constant at diurnal and seasonal scales, and temperature ranged from 0.01 to $11.6^{\circ} \mathrm{C}$. Malard et al. (2000) also observed that groundwater channels in the Roseg floodplain were clear and enriched in solutes, suggesting that groundwater is a major source of nutrients in the Val Roseg (also see Tockner et al. 1997). High nitrate concentrations in groundwater streams could also result from enhanced nitrification rates due to higher algal biomass or organic matter content in sediments (Tockner et al. 1997; Battin et al. 2004). The low concentrations of DOC found are typical for groundwater streams (Boyer et al. 1997). In upland catchments, soils and vegetation of the catchment are the primary sources of allochthonous DOC in streams, whereas snow DOC content is low (Boyer et al. 1997; Bernal and Sabater 2012).

Periphyton, measured as chlorophyll a and AFDM, varied strongly among as well as within the 5 mixed and groundwater streams examined. According to Uehlinger et al. (1998), groundwater alpine streams have greater periphyton biomass and chlorophyll a during summer than other seasons. However, this pattern was not observed in spring-summer in the present study. Generally, lower periphyton levels and complete absence of moss in all streams but stream $\mathrm{S} 3_{\mathrm{gw}}$ were primarily related to differences in hydrological regimes during summer (i.e. length of surface flow), which can affect, in particular, suspended sediment load, turbidity, hydraulic stress and bedload transport (e.g., Tockner et al. 1997; Malard et al. 1999). High variation in discharge coupled with sediment instability has been reported to be a major factor constraining periphyton levels in streams of high and low altitudes (Uehlinger 1991; Uehlinger and Naegeli 1998; Biggs et al. 1999, Singer et al. 2005). The low periphyton levels in the other study streams can be attributed to changes in discharge (or lack of) and other instream conditions. For instance, reduced water temperature, increased turbidity as well as increased shear stress through suspended solids can inhibit periphyton development, resulting in low periphyton levels (see Uehlinger et al. 2010).

Superimposed on these general effects of water source on periphyton levels, small-scale variations in water flow 
pathways and groundwater surface-water interactions, with linked changes in temperature and nutrients, can create spatial as well as temporal environmental gradients that are reflected in variations in periphyton levels in the study streams (Ward et al. 1999; Peterson et al. 2001; Battin et al. 2004; Roy et al. 2011). Besides these small scale effects, the change in temporal flow patterns may cause streams to fall dry, depending on the contribution of snowmelt or glacial meltwater and groundwater to discharge (Ward 1994). The duration, spatial extent and predictability of this kind of disturbance are important features that can limit epilithic communities in streams (Lake 2000, 2003; Humphries and Baldwin 2003). As we lack detailed annual flow data for the analyzed streams, the effect (intensity) of intermittency could not be evaluated here. Although periphyton are susceptible to desiccation if water levels drop (Steinman and McIntire 1990; Mosisch 2001), various studies have shown that algal assemblages have adapted to predictable disturbance events such as a gradual decrease in flow (Niemi et al. 1990; Steinman and McIntire 1990; Yount and Niemi 1990; Gasith and Resh 1999).

The third stream type observed were 'mixed' streams, which had low concentrations of nitrogen, intermediate concentrations of major ions (electrical conductivity) and TIC. Their discharge regime showed more variation (i.e. intermittency) than that of groundwater streams over the study period, and temperature ranged from 0.5 to $13.5^{\circ} \mathrm{C}$. Water source in mixed streams was likely a composite of snow-melt, glacier-melt and groundwater in which all contributed to discharge. An indicator for this mixed water source was the high variation regarding nitrogen, electrical conductivity, ionic composition and TIC (e.g., see Brown et al. 2003). The source of water for mixed streams likely changes over diel and annual hydrological cycles, e.g. less glacial input at night and in late autumn and winter, and likely influence their ecosystem properties over time in contrast to other stream types. More research is needed to more fully examine water ecosystem state variables in relation to water source dynamics.

Particulate $\mathrm{P}$ concentrations were highest in glacial streams and depended on discharge in mixed streams and glacial stream $\mathrm{S} 2_{\mathrm{g}}$. These results can be explained by the resuspension of glacial flour, which is characterized by high phosphorus concentrations, during high-flow periods (Bretschko 1966; Tockner et al. 1997). Glaciers also accumulate POM that is primarily blown in by aeolian drift and released during the melting period (Teeri and Barrett 1977). For instance, Tockner et al. (2002) found glacial streams to have higher POM concentrations than other streams in the Val Roseg. Varying meltwater production leads to high variation in discharge and thereby influences the release of POM (e.g., Romani et al. 2006) and partly explains the daily variation of POM in glacial stream $\mathrm{S} 2_{\mathrm{g}}$ that was much higher than in the other headwaters. FPOM correlated with discharge in all four examined streams, reflecting the resuspension of sediment that was correlated with discharge. These findings suggest that POM transport can be high in alpine headwater streams during periods of surface flow.

Organic matter inputs to the four study streams examined were generally low $\left(0.015-0.462 \mathrm{mg}\right.$ AFDM L $\left.{ }^{-1}\right)$ when compared with organic matter inputs in other Roseg streams that ranged between $2 \mathrm{mg} \mathrm{AFDM} \mathrm{L}{ }^{-1}$ (hillslope ground water) and $4 \mathrm{mg} \mathrm{AFDM} \mathrm{L}{ }^{-1}$ (glacial meltwater) (see Tockner et al. 2002). Zah and Uehlinger (2001), who also measured organic matter inputs along the Val Roseg, reported total annual inputs of POM ranging from $1.1 \mathrm{~g}$ $\mathrm{AFDM} \mathrm{m}^{-2}$ year $^{-1}$ close to the glacier to $10 \mathrm{~g}$ AFDM m ${ }^{-2}$ year $^{-1}$ in the floodplain section and finally a maximum of $34 \mathrm{~g} \mathrm{AFDM} \mathrm{m}^{-2}$ year $^{-1}$ in the lower forested section near the river mouth. In the study headwaters, FPOM was dominant, CPOM was the second most important fraction, followed by the invertebrate fraction. Allochthonous inputs to alpine streams are typically low but these inputs may be an important energy source because of limited algal growth in these streams (Tockner et al. 2002; this study). In the two streams examined, the total suspended organic matter at the downstream station was greater than at the upstream station above treeline. The low presence of riparian vegetation likely influenced the import of POM in the examined tributaries and explains the low values at sites above treeline. These findings suggest that POM concentrations increase from the upper basin to the lower basin, but also that fluxes from headwaters are likely to increase as alpine vegetation increases with climate associated changes (e.g., Mueller et al. 2013, Politti et al. 2014), thereby further influencing the water quality and quantity downstream (Alexander et al. 2007). Lastly, the spatial extent of intermittency among headwater streams can be important in organic matter fluxes in alpine catchments and is likely to increase in the future with ongoing glacial recession.

Sediment organic matter showed similar temporal patterns in the five examined headwaters, with a decline in June and subsequent increase in July and August. Organic matter content was lowest in June when discharge was maximum, indicating a strong hydrological control of POM in the uppermost hyporheic sediments. Several studies demonstrated that floods or spates result in significant reductions in benthic organic matter (Herbst 1980; Smock 1990; Naegeli et al. 1995; Naegeli et al. 1996). Gurtz and Tate (1988) found that in intermittent streams, large amounts of POM accumulated during dry periods and were transported and exported by floods. According to Metzler and Smock (1990), the stability of sediment is thought to be important for organic matter retention and supply of 
POM in streams, which in turn is influenced by variation in discharge. Thus, dry periods and floods can directly affect organic matter dynamics and organic matter processing in streams (Cuffney and Wallace 1989; Smock 1990; Boulton and Lake 1992; Naegeli et al. 1995), and likely are important for organic matter dynamics in alpine headwaters as well. For instance, bacterial community dynamics (Febria et al. 2012) and $p \mathrm{CO}_{2}$ outgassing (Peter et al. 2014) were associated with discharge fluctuations in alpine stream networks.

A functional aspect was assessed in five streams based on hyporheic sediment respiration. Average sediment respiration rates (ranging from 0.025 to $0.062 \mathrm{mg} \mathrm{O}_{2} \mathrm{~h}^{-1} \mathrm{~kg}^{-1}$ sediment) during the study period (May-August) were similar to levels reported from other alpine streams (Logue et al. 2004). Considering that $16 \%$ of the bed sediments belong to the size fraction $<8 \mathrm{~mm}$ (Zah et al. 2001) and that a sediment sample volume contained $2.73 \mathrm{~kg}$ sediments, average respiration in the uppermost $0.15 \mathrm{~m}$ streambed was $0.1 \pm 0.06 \mathrm{~g} \mathrm{O}_{2} \mathrm{~m}^{-3} \mathrm{~d}^{-1}$. These measured rates are quite low compared to non-alpine streams with values ranging from $7.9 \mathrm{~g} \mathrm{O}_{2} \mathrm{~m}^{-3} \mathrm{~d}^{-1}$ for a forested stream (Steina) in Germany (Pusch and Schwoerbel 1994) to $26.8 \mathrm{~g} \mathrm{O}_{2}$ $\mathrm{m}^{-3} \mathrm{~d}^{-1}$ for a desert stream (Sycamore) in southwest USA (Grimm and Fisher 1984). It is commonly agreed that organic matter is a major control of the heterotrophic metabolism in streambeds (Bott and Kaplan 1985; Jones et al. 1995; Findlay et al. 2003). At the catchment scale, total sediment organic matter explained $22 \%$ of the variation in hyporheic community respiration (data not shown) (also see Hedin 1990; Naegeli et al. 1995). Consequently, the transport of organic matter (although being $\leq 1.0 \mathrm{mg} / \mathrm{L}$ in these headwaters) and DOC with the onset of surface flows in intermittent alpine streams also can constrain instream metabolism (as respiration) in these ecosystems (Romani et al. 2006). Logue et al. (2004) also noted that respiration rates decreased later in the season (into September and October) as organic matter resources became limited in a high alpine catchment.

Besides total organic matter, different organic matter categories (LPOM $<0.063 \mathrm{~mm}$, SPOM $<0.063 \mathrm{~mm}$ ) had a significant influence on hyporheic sediment respiration. Pusch and Schwoerbel (1994) found LPOM to be closely related to hyporheic sediment respiration in a riffle pool sequence in a mountain stream. Our data indicate that, besides organic matter content, resource quality also might be an important factor controlling sediment respiration at the catchment scale. Small particles are expected to fuel hyporheic sediment respiration due to increased food quality (Hargrave 1972; King and Cummins 1989; Jones et al. 1995; this study). We expect that hyporheic sediment respiration at the stream scale is strongly influenced by hydrological dynamics as well as different water sources contributing to the discharge and organic matter inputs (including DOC: Baker et al. 2000) of the stream. For instance, although sediment respiration was not measured in glacial streams, DOC was lowest (ca. $0.25 \mathrm{mg} \mathrm{L}^{-1}$ ) in the glacial streams in this study and this suggests that hyporheic sediment respiration would be low in the streams as well. Hyporheic sediment respiration is reported to be influenced by abiotic factors such as the exchange between surface water and groundwater, texture, composition and grain size distribution of the hyporheic sediment, temperature, and nutrient availability (Grimm and Fisher 1984; Pusch and Schwoerbel 1994; Jones et al. 1995; Naegeli et al. 1996; Pusch 1996), which are ultimately controlled by discharge regime.

The combination of measures used in the present study showed that headwater streams in this alpine glacial catchment can show considerable variation in fundamental ecosystem processes such as production and respiration of organic matter. Our data suggest that distinct patterns of annual flow as well as daily variations in discharge and the contribution of different water sources may generate distinct patterns of productivity and change in-stream communities. Malard et al. (1999) showed that groundwater inputs play a major role in structuring ecological conditions in surface water habitats of the Roseg floodplain, thereby sustaining biodiversity and productivity in this so-called harsh environment. The contribution of different hydrological reservoirs to the flow of water within the catchment as well as location and strength of groundwater surface water exchange is predicted to change over time (e.g., Brown et al. 2007) with important implications regarding the conservation management of alpine landscapes (Khamis et al. 2014). Thus, it is essential to monitor ecosystem processes in relation to discharge and water origin over a period of at least a whole hydrological year (this study only encompassed early spring to late summer), which is also important when evaluating the effect of flow intermittency on aquatic biota.

Acknowledgments Special thanks to Richard Illi for analysis of water samples, and Rosi Siber and Michael Döring for assistance in GIS. Thanks to Thekla Ackermann, Fabio Gandolfi, Janine Rüegg and Marlène Zbinden for their support in the field. We also thank The Federal Office of Topography (Swisstopo) for access to aerial images. Several anonymous reviews assisted in improving an earlier version of the manuscript.

\section{References}

Acuna V, Tockner K (2010) The effects of alterations in temperature and flow regime on organic carbon dynamics in Mediterranean river networks. Glob Change Biol 16:2638-2650

Acuna V, Giorgi A, Munoz I, Uehlinger U, Sabater S (2004) Flow extremes and benthic organic matter shape the metabolism of a headwater Mediterranean stream. Freshw Biol 49:960-971 
Alexander RB, Boyer EW, Smith RA, Schwarz GE, Moore RB (2007) The role of headwater streams in downstream water quality. J Am Water Resour Assoc 43:41-59

APHA (1989) Standard methods for the examination of water and wastewater. American Public Health Association, Washington DC

Arthington AH, Bernado JM, Ilheu M (2014) Temporary rivers: linking ecohydrology, ecological quality and reconciliation ecology. River Res Appl 30:1209-1215

Baker MA, Valett HM, Dahm CN (2000) Organic carbon supply and metabolism in a shallow groundwater ecosystem. Ecology 81:3133-3148

Battin T, Wille A, Psenner R, Richter A (2004) Large-scale environmental controls on microbial biofilms in high-alpine streams. Biogeosciences 1:159-171

Battin T, Kaplan LA, Findlay S, Hopkinson CS, Marti E, Packman AI, Newbold JD, Sabater F (2008) Biophysical controls on organic carbon fluxes in fluvial networks. Nat Geosci 1:95-100

Bernal S, Sabater F (2012) Changes in discharge and solute dynamics between hillslope and valley-bottom intermittent streams. Hydrol Earth Syst Sci 16:1595-1605

Biggs BJF, Smith RA, Duncan MJ (1999) Velocity and sediment disturbance of periphyton in headwater streams: biomass and metabolism. J North Am Benthol Soc 18:222-241

Bocchiola D (2014) Long term (1921-2011) hydrological regime of alpine catchments in Northern Italy. Adv Water Resour 70:51-64

Bott TL, Kaplan LA (1985) Bacterial biomass, metabolic state, and activity in stream sediments-relation to environmental variables and multiple assay comparisons. Appl Environ Microbiol 50:508-522

Boulton AJ, Lake PS (1990) The ecology of two intermittent streams in Victoria, Australia. I. Multivariate analysis of physicochemical features. Freshw Biol 24:123-141

Boulton AJ, Lake PS (1992) Benthic organic matter and detritivorous macroinvertebrates in two intermittent streams in south-eastern Australia. Hydrobiologia 241:107-118

Boyer EW, Hornberger GM, Bencala KE, McKnight DM (1997) Response characteristics of DOC flushing in an alpine catchment. Hydrol Process 11:1635-1647

Bretschko G (1966) Untersuchungen zur Phosphatführung zentralalpiner Gletscherabflüsse. Archiv für Hydrobiologie 62:327-344

Brown LE, Hannah DM (2008) Spatial heterogeneity of water temperature across an alpine river basin. Hydrol Process 22:954-967

Brown LE, Hannah DM, Milner AM (2003) Alpine stream habitat classification: an alternative approach incorporating the role of dynamic water source contributions. Arct Antarct Alp Res 35:313-322

Brown LE, Hannah DM, Milner AM (2007) Vulnerability of alpine stream biodiversity to shrinking glaciers and snowpacks. Glob Change Biol 13:958-966

Buttle JM, Boon S, Peters DL, Spence C, (Ilja) van Meerveld HJ, Whitfield PH (2012) An overview of temporary stream hydrology in Canada. Can Water Resour J 37:279-310

Comin FA, Williams WD (1994) Parched continents: our common future? In: Margalef R (ed) Limnology now a paradigm of planetary problems. Elsevier, Amsterdam, pp 473-527

Covich AP, Fritz SC, Lamb PJ, Marzolf RD, Matthews WJ, Poiani KA, Prepas EE, Richman MB, Winter TC (1997) Potential effects of climate change on aquatic ecosystems of the Great Plains of North America. Hydrol Process 11:993-1021

Cuffney TF, Wallace JB (1989) Discharge-export relationships in headwater streams -the influence of invertebrate manipulations and drought. J North Am Benthol Soc 8:331-341

Datry T, Larned ST, Tockner K (2014) Intermittent rivers: a challenge for freshwater ecology. Bioscience 64:229-235
Dieterich M, Anderson NH (1998) Dynamics of abiotic parameters, solute removal and sediment retention in summer-dry headwater streams of western Oregon. Hydrobiologia 379:1-15

Doering M, Uehlinger U, Tockner K (2013) Vertical hydrological exchange, and ecosystem properties and processes at to spatial scales along a floodplain river (Tagliamento, Italy). Freshw Sci 32:12-25

Donath U, Robinson CT (2001) Ecological characteristics of lake outlets in Alpine environments of the Swiss Alps. Archiv für Hydrobiologie 150:207-225

Downes MT (1978) Improved hydrazine reduction method for automated-determination of low nitrate levels in freshwater. Water Res 12:673-675

Ebina J, Tsutsui T, Shirai T (1983) Simultaneous determination of total nitrogen and total phosphorus in water using peroxodisulfate oxidation. Water Res 17:1721-1726

Febria CM, Beddoes P, Fulthorpe RR, Williams DD (2012) Bacterial community dynamics in the hyporheic zone of an intermittent stream. ISME J 6:1078-1088

Findlay SEG, Sinsabaugh RL, Sobczak WV, Hoostal M (2003) Metabolic and structural response of hyporheic microbial communities to variations in supply of dissolved organic matter. Limnol Oceanogr 48:1608-1617

Fisher SG, Gray LJ, Grimm NB, Busch DE (1982) Temporal succession in a desert stream ecosystem following flash flooding. Ecol Monogr 52:93-110

Fountain AG (1996) Effect of snow and firn hydrology on the physical and chemical characteristics of glacial runoff. Hydrol Process 10:509-521

Fritz KM, Hagenbuch E, D'Amico E, Reif M, Wigington PJ, Leibowitz SG, Comeleo RL, Ebersole JL, Nadeau T (2013) Comparing the extent and permanence of headwater streams from two field surveys to values from hydrographic databases and maps. J Am Water Resour Assoc 49:867-882

Gasith A, Resh VH (1999) Streams in Mediterranean climate regions: abiotic influences and biotic responses to predictable seasonal events. Annu Rev Ecol Syst 30:51-81

Gordon ND, McMahon TA, Finlayson BL, Nathan RJ, MacMahon TA (1992) Stream hydrology: an introduction for ecologists. Wiley, Chichester

Grimm NB, Fisher SG (1984) Exchange between interstitial and surface-water-implications for stream metabolism and nutrient cycling. Hydrobiologia 111:219-228

Gurtz ME, Tate CM (1988) Hydrologic influences on leaf decomposition in a channel and adjacent bank of a gallery forest stream. Am Midl Nat 120:11-21

Hargrave BT (1972) Aerobic decomposition of sediment and detritus as a function of particle surface-area and organic content. Limnol Oceanogr 17:583-593

Hedin LO (1990) Factors controlling sediment community respiration in woodland stream ecosystems. Oikos 57:94-105

Herbst GN (1980) Effects of burial on food value and consumption of leaf detritus by aquatic invertebrates in a lowland forest stream. Oikos 35:411-424

Heuer K, Brooks PD, Tonnessen KA (1999) Nitrogen dynamics in two high elevation catchments during spring snowmelt 1996, Rocky Mountains, Colorado. Hydrol Process 13:2203-2214

Hieber M (2002) Alpine streams: aspects of biocomplexity. Dissertation, ETH-Zürich, Zürich

Hieber M, Robinson CT, Uehlinger U, Ward JV (2002) Are alpine lake outlets less harsh than other alpine streams? Archiv für Hydrobiologie 154:199-223

House HR, McKnight DM, Von Guerard P (1995) The influence of stream channel characteristics on streamflow and annual water budgets for lakes in Taylor Valley. Antarct J U S Rev $34: 284-287$ 
Humphries P, Baldwin DS (2003) Drought and aquatic ecosystems: an introduction. Freshw Biol 48:1141-1146

IPCC (2014) Climate change 2014: synthesis report. Cambridge University Press, Cambridge

Johannessen MT, Dale ET, Gjessing A, Henriksen A, Wright RF (1977) Acid precipitation in Norway: the regional distribution of contaminants in snow and the chemical concentration processes during snowmelt. In: Proceedings of the international symposium on isotopes and impurities in snow and ice, international association of hydro-logical sciences, IAHS, pp 116-120

Jones JB (1995) Factors controlling hyporheic respiration in a desert stream. Freshw Biol 34:91-99

Jones JB, Fisher SG, Grimm NB (1995) Vertical hydrologic exchange and ecosystem metabolism in a Sonoran Desert stream. Ecology 76:942-952

Khamis K, Hannah DM, Hill Clarvis M, Brown LE, Castella E, Milner AM (2014) Alpine aquatic ecosystem conservation policy in a changing climate. Environ Sci Policy 43:39-55

King DK, Cummins KW (1989) Factors affecting autotrophicheterotrophic relationships of a woodland stream. J Freshw Ecol $5: 15-26$

Lake PS (2000) Disturbance, patchiness, and diversity in streams. J North Am Benthol Soc 19:573-592

Lake PS (2003) Ecological effects of perturbation by drought in flowing waters. Freshw Biol 48:1161-1172

Langston G, Bentley LR, Hayashi M, McClymont A, Pidlisecky A (2011) Internal structure and hydrological functions of an alpine proglacial moraine. Hydrol Process 25:2967-2982

Larned ST, Datry T, Robinson CT (2007) Invertebrate and microbial responses to inundation in an ephemeral river reach in New Zealand: effects of preceding dry periods. Aquat Sci 69:554-567

Larned ST, Datry T, Arscott DB, Tockner K (2010) Emerging concepts in temporary-river ecology. Freshw Biol 55:717-738

Lencioni V, Marziali L, Rossaro B (2012) Chironomids as bioindicators of environmental qualtiy in mountain springs. Freshw Sci 31:525-541

Logue AB, Robinson CT, Meier C, Van der Meer JR (2004) Relationship between sediment organic matter, bacteria composition, and the ecosystem metabolism of alpine streams. Limnol Oceanogr 49:2001-2010

Magnusson J, Kobierska F, Huxol S, Hayashi M, Jonas T, Kirchner JW (2014) Melt water driven stream and groundwater stage fluctuations on a glacier forfield (Dammagletscher, Switzerland). Hydrol Process 28:823-836

Malard F (2003) Groundwater-surface water interactions. In: Ward JV, Uehlinger U (eds) Ecology of a glacial floodplain. Kluwer Academic Publishers, Dordrecht, pp 37-56

Malard F, Tockner K, Ward JV (1999) Shifting dominance of subcatchment water sources and flow paths in a glacial floodplain, Val Roseg, Switzerland. Arct Antarct Alp Res 31:135-150

Malard F, Tockner K, Ward JV (2000) Physico-chemical heterogeneity in a glacial riverscape. Landscape Ecol 15:679-695

Malard F, Uehlinger U, Zah R, Tockner K (2005) Flood-pulse and riverscape dynamics in a braided glacial river. Ecology $87: 704-716$

Matthews WJ (1988) North American prairie streams as systems for ecological study. J N Am Benthol Soc 7:387-409

Metzler GM, Smock LA (1990) Storage and dynamics of subsurface detritus in a sand-bottomed stream. Can J Fish Aquat Sci 47:588-594

Meyer A, Meyer EI, Meyer C (2003) Lotic communities of two small temporary karstic stream systems (East Westphalia, Germany) along a longitudinal gradient of hydrological intermittency. Limnologica 33:271-279
Meyer JL, Strayer DL, Wallace JB, Eggert SL, Helfman GS, Leonard NE (2007) The contribution of headwater streams to biodiversity in river networks. J Am Water Resour Assoc 43:86-103

Meyns S, Illi R, Ribi B (1994) Comparison of chlorophyll- $a$ analysis by HPLC and spectrophotometry: where do the differences come from? Archiv für Hydrobiologie 132:129-139

Milner AM, Petts GE (1994) Glacial rivers - physical habitat and ecology. Freshw Biol 32:295-307

Mosisch TD (2001) Effects of desiccation on stream epilithic algae. NZ J Mar Freshwat Res 35:173-179

Mueller MH, Weingartner R, Alewell C (2013) Importance of vegetation, topography and flow paths for water transit times of base flow in alpine headwater catchments. Hydrol Earth Syst Sci 17:1661-1679

Naegeli MW, Hartmann U, Meyer EI, Uehlinger U (1995) POMdynamics and community respiration in the sediments of a floodprone prealpine river (Necker, Switzerland). Archiv für Hydrobiologie 133:339-347

Naegeli MW, Huggenberger P, Uehlinger U (1996) Ground penetrating radar for assessing sediment structures in the hyporheic zone of a prealpine river. J North Am Benthol Soc 15:353-366

Niemi GJ, Devore P, Detenbeck N, Taylor D, Lima A, Pastor J, Yount JD, Naiman RJ (1990) Overview of case-studies on recovery of aquatic systems from disturbance. Environ Manage 14:571-587

Perrot D, Molotch NP, Williams MW, Jepsen SM, Sickman JO (2014) Relationships between stream nitrate concentration and spatially distributed snowmelt in high-elevation catchments of the western U.S. Water Resour Res 50:8694-8713

Peter H, Singer GA, Preiler C, Chifflard P, Steniczka G, Battin TJ (2014) Scales and drivers of temporal $p \mathrm{CO}_{2}$ dynamics in an Alpine stream. J Geophys Res Biogeosci 119:1078-1091

Peterson CG, Valett HM, Dahm CN (2001) Shifts in habitat templates for lotic microalgae linked to interannual variation in snowmelt intensity. Limnol Oceanogr 46:858-870

Politti E, Egger G, Angermann K, Rivaes R, Blamauer B, Klösch M, Trutthart M, Habersack H (2014) Evaluating cliamte change impacts on Alpine floodplain vegetation. Hydrobiologia 737:225-243

Pusch M (1996) The metabolism of organic matter in the hyporheic zone of a mountain stream, and its spatial distribution. Hydrobiologia 323:107-118

Pusch M, Schwoerbel J (1994) Community respiration in hyporheic sediments of a mountain stream (Steina, Black-Forest). Archiv für Hydrobiologie 130:35-52

Reid LM, Ziemer RR (1994) Evaluating the biological significance of intermittent streams. USDA Forest Service, Pacific Southwest Research Station

Robinson CT, Matthaei S (2007) Hydrological heterogeneity of an Alpine stream/lake network in Switzerland. Hydrol Process 21:3146-3154

Robinson CT, Burgherr P, Malard F, Tockner K, Uehlinger U (2003) Synthesis and perspectives. In: Ward JV, Uehlinger U (eds) Ecology of a glacial flood plain. Kluwer Academic Publishers, Dordrecht, pp 257-269

Rocha LG, Medeiros ESF, Andrade HTA (2012) Influence of flow variability on macroinvertebrate assemblages in an intermittent stream of semi-arid Brazil. J Arid Environ 85:33-40

Rodier D (1996) L'analyse de l'Eau. Dunod, Paris

Romani AM, Vazquez E, Butturini A (2006) Microbial availability and size fractionation of dissolved organic carbon after drought in an intermittent stream: biogeochemical link across the streamriparian interface. Microb Ecol 52:501-512

Röthlisberger H, Lang H (1987) Glacial hydrology. In: Clark MJ, Gurnell AM (eds) Glacio-fluvial sediment transfer: an alpine perspective. Wiley, Chichester, pp 207-284 
Roy JW, Zaitlin B, Hayashi M, Watson SB (2011) Influence of groundwater spring discharge on small-scale spatial variation of an alpine stream ecosystem. Ecohydrology 4:661-670

Ruegg J, Robinson CT (2004) Comparison of macroinvertebrate assemblages of permanent and temporary streams in an Alpine floodplain, Switzerland. Archiv für Hydrobiologie 161:489-510

Rutter N, Hodson A, Irvine-Fynn T, Molas MK (2011) Hydrology and hydrochemistry of a deglaciating high-Arctic catchment, Svalbard. J Hydrol 410:39-50

Sertic Peric M, Jolidon C, Uehlinger U, Robinson CT (2015) Longterm ecological patterns of alpine streams: an imprint of glacial legacies. Limnol Oceanogr doi:10.1002/lno.2014.00.00.10069

Singer GA, Panzenbock M, Weigelhofer G, Marchesani C, Waringer J, Wanek W, Battin TJ (2005) Flow history explains temporal and spatial variation of carbon fractionation in stream periphyton. Limnol Oceanogr 50:706-712

Slemmons KEH, Saros JE, Simon K (2013) The influence of glacial meltwater on alpine aquatic ecosystems: a review. Environ Sci Process Impacts 15:1794-1806

Smock LA (1990) Spatial and temporal variation in organic matter storage in low-gradient, headwater streams. Archiv für Hydrobiologie 118:169-184

Stanley EH, Boulton AJ (1995) Hyporheic processes during flooding and drying in a Sonoran desert stream. 1. Hydrol Chem Dyn. Archiv für Hydrobiologie 134:1-26

Stanley EH, Fisher SG, Grimm NB (1997) Ecosystem expansion and contraction in streams. Bioscience 47:427-435

Steinman AD, McIntire CD (1990) Recovery of lotic periphyton communities after disturbance. Environ Manage 14:589-604

Teeri J, Barrett PE (1977) Detrital transport by wind in an high arctic terrestrial ecosystem. Arct Antarct Alp Res 7:387-391

Tockner K, Malard F (2003) Channel typology. In: Ward JV, Uehlinger U (eds) Ecology of a glacial floodplain. Kluwer Academic Publishers, Dordrecht, pp 57-73

Tockner K, Malard F, Burgherr P, Robinson CT, Uehlinger U, Zah R, Ward JV (1997) Physico-chemical characterization of channel types in a glacial floodplain ecosystem (Val Roseg, Switzerland). Archiv für Hydrobiologie 140:433-463

Tockner K, Malard F, Uehlinger U, Ward JV (2002) Nutrients and organic matter in a glacial river-floodplain system (Val Roseg, Switzerland). Limnol Oceanogr 47:266-277

Tonolla D, Acuna V, Uehlinger U, Frank T, Tockner K (2010) Thermal heterogeneity in river floodplains. Ecosystems 13:727-740

Tooth S (2000) Process, form and change in dryland rivers: a review of recent research. Earth Sci Rev 5:67-107
Uehlinger U (1991) Spatial and temporal variability of the periphyton biomass in a prealpine river (Necker, Switzerland). Archiv für Hydrobiologie 123:219-228

Uehlinger U, Naegeli MW (1998) Ecosystem metabolism, disturbance, and stability in a prealpine gravel bed river. J N Am Benthol Soc 17:165-178

Uehlinger U, Bossard P, Bloesch J, Bürgi HP, Bührer H (1984) Ecological experiments in limnocorals: methodological problems and quantification of the epilimnetic phosphorus and carbon cycles. Verhandlungen der Internationalen Vereinigung für Theoretische und Angewandte Limnologie 22:163-171

Uehlinger U, Zah R, Buergi H (1998) The Val Roseg project: temporal and spatial patterns of benthic algae in an Alpine stream ecosystem influenced by glacier runoff. In: Kovar K, Tappeiner U, Peters NE, Graig RG (eds) Hydrology, water resources and ecology in headwaters. IAHS Press, Willingford, pp 419-424

Uehlinger U, Robinson CT, Hieber M, Zah R (2010) The physicochemical habitat template for periphyton in alpine glacial streams under a changing climate. Hydrobiologia 657:107-121

Vidal-Abarca MR, Sanchez-Montoya MM, Guerrero C, Gomez R, Arce MI, Garcia-Garcia V, Suarez ML (2013) Effects of intermittent stream flow on macroinvertebrate community composition and biological traits in a naturally saline Mediterranean stream. J Arid Environ 99:28-40

Ward JV (1994) Ecology of alpine streams. Freshw Biol 32:277-294

Ward JV, Uehlinger U (eds) (2003) Ecology of a glacial flood plain. Kluwer Academic Publishers, Dordrecht

Ward JV, Malard F, Tockner K, Uehlinger U (1999) Influence of ground water on surface water conditions in a glacial flood plain of the Swiss Alps. Hydrol Process 13:277-293

Yount JD, Niemi GJ (1990) Recovery of lotic communities and ecosystems from disturbance - A narrative review of casestudies. Environ Manage 14:547-569

Zah R, Uehlinger U (2001) Particulate organic matter inputs to a glacial stream ecosystem in the Swiss Alps. Freshw Biol 46:1597-1608

Zah R, Niederost M, Rinderspacher H, Uehlinger U, Ward JV (2001) Long-term dynamics of the channel network in a glacial floodplain, Val Roseg, Switzerland. Arct Antarct Alp Res 33:440-446

Zah R, Maisch M, Uehlinger U, Rothenbühler C (2003) Glacial history and floodplain evolution. In: Ward JV, Uehlinger U (eds) Ecology of a glacial floodplain. Kluwer Academic Publishers, Dordrecht, pp 17-36

Zar JH (1984) Biostatistical analysis. Prentice-Hall, Englewood Cliffs 